\title{
Influence of Glass Powder on the Properties Of Concrete
}

\author{
Veena V. Bhat ${ }^{1}$, N. Bhavanishankar Rao ${ }^{2}$ \\ ${ }^{I}$ M. Tech. final year student \\ ${ }^{2}$ Professor, Civil Engineering Department \\ ${ }^{1,2}$ N M AM Institute of Technology, Nitte , 574110, Karnataka, India
}

\begin{abstract}
Glass is commonly used in building / construction industries and large amount of glass is powdered daily. The disposal of waste glass is an environmental issue as waste glass causes disposal problem.

Today the construction industry is in need of finding cost effective materials for increasing the strength of concrete structures. Glass powder finer than $600 \mu$ is reported to have pozzolanic behaviour. An attempt is made to investigate the possibility of using the waste glass powder as the partial replacement of ordinary Portland cement in concrete. Concrete with replacement of cement by waste glass powder such as $5 \%$, $10 \%, 15 \%$ and $20 \%$ were produced and properties of this concrete has been compared with concrete of control mix with no replacement.

Cube specimens of 24 numbers were cast, cured and tested for 7 day and 28 days strength. Compression test was conducted and the results were compared. The findings revealed an increase in compressive strength with the increase in the replacement of cement by glass powder. To reduce the demand for cement, glass powder replacements can be adopted. The replacement of glass powder decreases the unit weight as well as the porosity as indicated by the decrease in water absorption. It reduces the quantity of cement to be used in concrete. Also glass powder is proved to be economical and is considered as environmental friendly construction material.
\end{abstract}

Keywords - Glass powder, solid waste, compressive strength, curing, replacement of cement, cost effective material.

\section{INTRODUCTION}

Due to global warming the need to cut down energy consumption has increased. The effect of global warming has impacted everyone on the planet and is a well recognised concept ${ }^{1}$.

The interest of construction community in using waste or recycled materials in concrete is increasing because of the emphasis placed on sustainable construction. Presently the waste glass in and around the small shops is packed as a waste and disposed as landfill ${ }^{4}$.

Waste glass contain high silica ( $\mathrm{SiO} 2)$ i.e. $72 \%$. Waste glass when ground to very fine powder $(600$ micron) reacts with alkalis in cement (pozzolanic reaction) and cementitious product that help contribute to the strength development ${ }^{2}$.

\section{OBJECTIVES OF THE INVESTIGATION}

Experiments were conducted on concrete prepared by partial replacement of cement by waste glass powder of particle size 600 micron and downwards.

The main objective of this investigation was to evaluate the effect of waste glass powder on the compressive strength and the other properties of concrete and to evaluate the possibility of using glass powder in concrete without sacrificing the strength. The following were also considered.

- Partial substitute for the ordinary portland cement

- To investigate the structural behaviour of such replaced concrete components

- To determine the percentage of glass powder which gives maximum strength when compared to control concrete

\section{EXPERIMENTAL PROCEDURE}

\section{A. Materials used}

Ordinary Portland cement of 53 grade is used in the experiment. Sand of particle size $4.75 \mathrm{~mm}$ downwards coarse aggregate of $20 \mathrm{~mm}$ and glass powder of size 600 micron downwards is used in the experimental work.

The properties of materials used are Specific gravity of cement $\quad=3.15$

Specific gravity of fine aggregate $\quad=2.50$

Specific gravity of coarse aggregate $=2.80$

Specific gravity of glass powder $\quad=2.45$

Fineness modulus of coarse aggregate $=7.36$

Fineness modulus of fine aggregate $\quad=2.90$ 


\section{B. Experimental Plan}

In this work, $5 \%, 10 \%, 15 \%$ and $20 \%$ of ordinary portland cement is replaced by glass powder for M25 grade concrete.

Cube specimens of size $150 \mathrm{~mm}$ x $150 \mathrm{~mm}$ x 150 $\mathrm{mm}$ of 18 numbers were casted for different proportions with glass powder and compared with the properties of concrete prepared without glass powder (control mix). Compression test was performed on the concrete after 7 and 28 days of curing.

\section{The mix design}

The mix design for M25 grade concrete was made using 1S 456:2000, IS 10262:2009. The materials required as per design are given in Table 1.

TABLE I

MATERIALS REQUIRED AS PER IS METHOD OF DESIGN FOR CONTROL CONCRETE

\begin{tabular}{|l|l|l|l|}
\hline \multirow{2}{*}{$\begin{array}{l}\text { w/c } \\
\text { ratio }\end{array}$} & \multicolumn{3}{|c|}{ Quantity of Materials $\left(\mathbf{k g} / \mathbf{m}^{3}\right)$} \\
\cline { 2 - 4 } & Cement & $\begin{array}{l}\text { Fine } \\
\text { aggregate }\end{array}$ & Coarse aggregate \\
\hline 0.54 & 350 & 740.740 & 1234.567 \\
\hline
\end{tabular}

\section{Mix proportions}

The mix proportion was obtained for various percentages of glass powder i.e., $5 \%, 10 \%, 15 \%$, and $20 \%$ replacement for ordinary portland cement. In the first trial, water content was maintained constant. However in the second trial water /cement ratio was maintained constant. The mix proportions for various batches for trial I and trial II are given in table II and table III respectively.

TABLE II

DETAILS OF MIX PROPORTIONS FOR TRIAL I

\begin{tabular}{|l|l|l|l|l|}
\hline \multirow{2}{*}{$\begin{array}{l}\text { Glass } \\
\text { powd } \\
\text { er } \\
(\%)\end{array}$} & $\begin{array}{l}\text { Cement } \\
\left(\mathbf{k g} / \mathbf{m}^{\mathbf{3}}\right)\end{array}$ & $\begin{array}{l}\text { Fine } \\
\text { aggregate } \\
\left(\mathbf{k g} / \mathbf{m}^{\mathbf{3}}\right)\end{array}$ & $\begin{array}{l}\text { Coarse } \\
\text { aggregate } \\
\left(\mathbf{k g} / \mathbf{m}^{\mathbf{3}}\right)\end{array}$ & $\begin{array}{l}\text { Water } \\
\text { content } \\
\left(\mathbf{k g} / \mathbf{m}^{\mathbf{3}}\right)\end{array}$ \\
\hline 0 & 350.00 & 740.74 & 1234.56 & 188.00 \\
\hline 5 & 332.49 & 680.49 & 1159.01 & 188.00 \\
\hline 10 & 314.96 & 669.13 & 1139.25 & 188.00 \\
\hline 15 & 297.48 & 655.30 & 1116.04 & 188.00 \\
\hline 20 & 280.00 & 641.97 & 1093.33 & 188.00 \\
\hline
\end{tabular}

TABLE III

DETAILS OF MIX PROPORTIONS FOR TRIAL II

\begin{tabular}{|l|l|l|l|l|}
\hline \multirow{2}{*}{$\begin{array}{l}\text { Glass } \\
\text { powd } \\
\text { er } \\
(\%)\end{array}$} & $\begin{array}{l}\text { Cement } \\
\left(\mathrm{kg} / \mathrm{m}^{3}\right)\end{array}$ & $\begin{array}{l}\text { Fine } \\
\text { aggregate } \\
\left(\mathrm{kg} / \mathrm{m}^{3}\right)\end{array}$ & $\begin{array}{l}\text { Coarse } \\
\text { aggregate } \\
\left(\mathrm{kg} / \mathrm{m}^{3}\right)\end{array}$ & $\begin{array}{l}\text { Water } \\
\text { content } \\
\left(\mathrm{kg} / \mathrm{m}^{3}\right)\end{array}$ \\
\hline
\end{tabular}

\begin{tabular}{|l|l|l|l|l|}
\hline 0 & 350.00 & 740.74 & 1234.56 & 188.00 \\
\hline 5 & 332.49 & 680.49 & 1159.01 & 179.54 \\
\hline 10 & 314.96 & 669.13 & 1139.25 & 170.07 \\
\hline 15 & 297.48 & 655.30 & 1116.04 & 160.63 \\
\hline 20 & 280.00 & 641.97 & 1093.33 & 151.20 \\
\hline
\end{tabular}

In the first case, the strength of cubes was decreased with the increase in the percentage of glass powder. Therefore in the second trial, water/ cement ratio was maintained constant because glass powder was not utilizing water for reaction.

\section{E. Tests on specimens}

All the cast specimens were de-moulded after 24 hours and were placed in curing tank for a period of 7 to 28 days. The specimens were tested in the compression testing machine of 200 tonne capacity.

Three numbers of specimens in each were tested and the average value was calculated. The results were compared with that of control mix.

The test set up and the failure pattern of specimens for compression test is shown in Fig. 1.

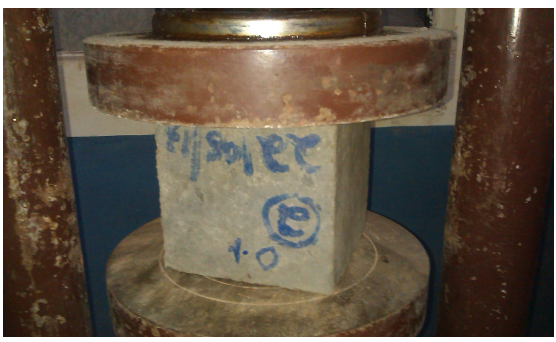

Fig. 1 Compression test set up

\section{F. Compression test}

The table IV and table V shows the overall results of development of compressive strength in concrete with age for trial I and trial II respectively.

TABLE IV

RES ULTS OF COMPRESSIVE STRENGTH TEST OF CONCRETE FOR TRIAL I

\begin{tabular}{|l|l|l|}
\hline \multirow{2}{*}{$\begin{array}{l}\text { Glass } \\
\text { powder } \\
(\%)\end{array}$} & \multicolumn{2}{|c|}{ Compressive Strength, MPa } \\
\cline { 2 - 3 } & $\mathbf{7}$ days & 28days \\
\hline 0 & 22.37 & 28.37 \\
\hline 5 & 10.66 & 18.66 \\
\hline 10 & 10.22 & 17.58 \\
\hline 15 & 08.14 & 17.03 \\
\hline 20 & 08.14 & 15.85 \\
\hline
\end{tabular}


TABLE V

RESULTS OF COMPRESSIVE STRENGTH TEST OF CONCRETE FOR TRIAL II

\begin{tabular}{|l|l|l|}
\hline $\begin{array}{l}\text { Glass } \\
\text { powder } \\
(\%)\end{array}$ & \multicolumn{2}{|c|}{ Compressive Strength, MPa } \\
\cline { 2 - 3 } & $\mathbf{7}$ days & 28days \\
\hline 0 & 22.37 & 28.37 \\
\hline 5 & 23.40 & 29.70 \\
\hline 10 & 24.80 & 31.30 \\
\hline 15 & 26.66 & 33.36 \\
\hline 20 & 29.92 & 36.12 \\
\hline
\end{tabular}

The graph shown in Fig.2. and Fig. 3. illustrates the variation of the compressive strength of specimens with different percentage replacement of cement by glass powder for trial I and trial II respectively.

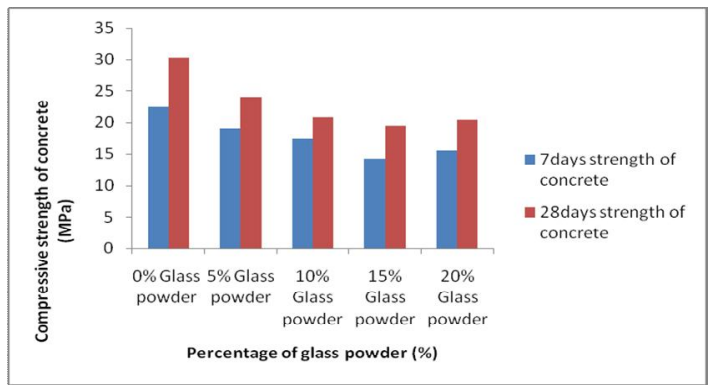

Fig. 2 Compressive strength v/s glass powder (\%) for trial I

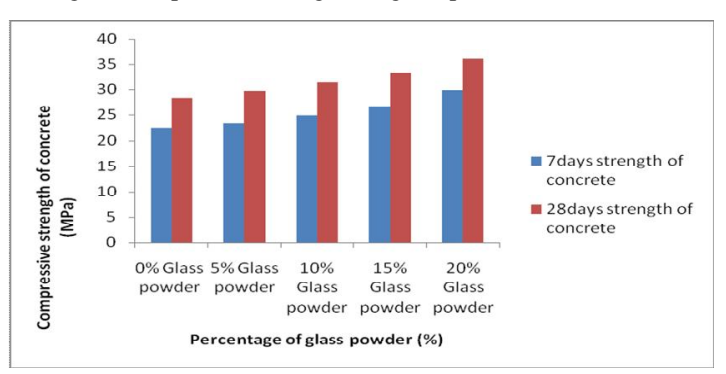

Fig. 3 Compressive strength v/s glass powder (\%) for trial II

\section{G. Unit Weight of the Cube}

Tests to study the variation of unit weight of the cube was conducted only for trial II. The table VI shows the details about the unit weight of the cube with the increase in the percentage of the glass powder in concrete.

TABLE VI

UNIT WEIGHT OF THE CONCRETE CUBE

\begin{tabular}{|l|l|l|}
\hline $\begin{array}{l}\text { Glass } \\
\text { powder } \\
(\%)\end{array}$ & $\begin{array}{l}\text { Weight of the cube } \\
(\mathbf{k g})\end{array}$ & $\begin{array}{l}\text { Unit Weight } \\
\text { of the cube } \\
\left(\mathbf{k g} / \mathbf{m}^{\mathbf{3}}\right)\end{array}$ \\
\hline 0 & 8.150 & 2414.81 \\
\hline 5 & 8.130 & 2408.88 \\
\hline 10 & 8.110 & 2402.96 \\
\hline
\end{tabular}

\begin{tabular}{|l|l|l|}
\hline 15 & 8.050 & 2385.19 \\
\hline 20 & 7.970 & 2361.48 \\
\hline
\end{tabular}

The graph shown in Fig. 4. illustrates the variation of the unit weight of the cube with different percentage replacement of cement by glass powder.

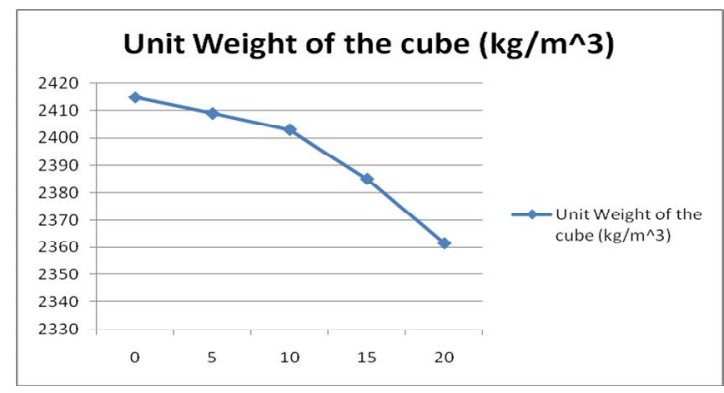

Fig. 4 Unit weight of the cube v/s glass powder (\%) for trial II

\section{H. Porosity test}

Water absorption test or the porosity test was carried out the percentage water absorption was measured. The table VII shows the details about the water absorption test carried out.

TABLE VII

RESULTS OF WATER ABSORPTION TEST ON CONCRETE

\begin{tabular}{|l|l|l|l|l|}
\hline $\begin{array}{l}\text { Waste } \\
\text { glass } \\
\text { content } \\
\text { in } \%\end{array}$ & $\begin{array}{l}\text { Average } \\
\text { dry } \\
\text { weight } \\
(\mathrm{g})\end{array}$ & $\begin{array}{l}\text { Average } \\
\text { wet } \\
\text { weight } \\
(\mathrm{g})\end{array}$ & $\begin{array}{l}\text { Water } \\
\text { absorbed } \\
(\mathrm{g})\end{array}$ & $\begin{array}{l}\text { Percentage } \\
\text { water } \\
\text { absorption } \\
(\%)\end{array}$ \\
\hline 0 & 8133 & 8231 & 98 & 1.204 \\
\hline 5 & 8053 & 8125 & 72 & 0.894 \\
\hline 10 & 8002 & 8062 & 60 & 0.749 \\
\hline 15 & 7987 & 8038 & 51 & 0.638 \\
\hline 20 & 7952 & 7993 & 41 & 0.516 \\
\hline
\end{tabular}

\section{DISCUSSION OF TEST RESULTS}

The influence of waste glass powder on the properties of concrete such as the compressive strength, unit weight, slump and the percentage water absorption are studied. In the trial I decrease in the compressive strength is shown with the increase in glass powder in concrete. This may be due to increase in water/cement ratio with constant water used in the mix.

In the trial II increase in strength is shown with the increase in glass powder in concrete. This is due to constant water/cement ratio maintained for all the mixes. 
An appreciable increase in the compressive strength is observed in trial II with the increase in the percentage replacement of cement by glass powder from $5 \%$ to $20 \%$. With $20 \%$ replacement the increase in strength is $27 \%$. As the replacement of glass powder increases, unit weight of the cube decreases. This effect is due to lower specific gravity of glass powder compared to that of cement. However, the strength increase has taken place because of pozzolanic action of glass powder. Since the glass powder acts as a pozzolanic material the affect of carbonation is reduced and the durability of concrete increases. The results confirms the statement made in reference [3], "The smaller particle size of the glass powder has higher activity with lime present in the cement resulting in higher compressive strength in the concrete mix" ". Slump was found to be $70-72 \mathrm{~mm}$. When the water cement ratio was maintained constant in the mix the slump was found to be increasing. The percentage water absorption decreased with increase in broken glass content. The lowest value of water absorption was found for concrete mix with $20 \%$ broken glass content.

\section{CONCLUSIONS}

The influence of replacement of cement by glass powder has been studied. Based on the experimental work conducted, the following conclusions are drawn.

The replacement of cement by glass powder in concrete increases the compressive strength of concrete. Increase of $27 \%$ strength can be achieved when $20 \%$ cement was replaced by glass powder in concrete when water/ cement ratio was maintained constant. Slump test was carried out and the slump was found to be 70 to $72 \mathrm{~mm}$ even with $20 \%$ replacement. With the increase in glass content, percentage of water absorption decreases. Considering the strength criteria, the replacement of cement by glass powder is feasible upto $20 \%$. Usage of waste glass powder in concrete can prove to be economical as it is very much cheaper than cement. Use of waste glass in concrete will reduce the disposal problem of waste glass and prove to be environmental friendly thus paving for green concrete ${ }^{5}$.

\section{ACKNOWLEDGMENT}

Experimental work was carried out using the facilities in Civil Engineering Department laboratory of NMAM institute of Technology. The authors wish to thank the authorities of NMAM institute of Technology for their kind support. Authors also wish to thank the laboratory staff for their help and support during experimental work.

\section{REFERENCES}

[1] J.M. Khatib, E.M. Negim, H.S. Sohl and N. Chileshe, "Glass Powder Utilisation in Concrete Production," European Journal of Applied Sciences 4 (4): 173-176, 2012.

[2] M.N. Bajad, C.D. Modhera and A.K. Desai, "Higher Strength Concrete using Glass Powder," Journal of Structural Engineering, Vol. 39, No. 3, August-September 2012, pp. 380-383.

[3] Ankur Meena and Randheer Singh Karnik, "Comparative Study of Waste Glass Powder as Pozzolanic Material in Concrete," B. Tech. thesis, National Institute of Technology, Rourkela, 2012.

[4] G. Vijayakumar, H. Vishaliny, D. Govindarajulu, "Studies on Glass Powder as Partial Replacement of Cement in Concrete Production," International Journal of Emerging Technology and Advanced Engineering, Vol. 3, Issue 2, Febraury 2013, pp. 153-157.

[5] M. Iqbal Malik, Muzafar Bashir, Sajad Ahmad, Tabish Tariq, Umar Chowdhary, "Study of Concrete Involving Use of Waste Glass as Partial Replacement of Fine Aggregates," IOSR Journal of Engineering, Vol. 3, Issue 7 (July 2013), pp. 08-13. 